\title{
Relational and Identity-Making Capabilities in the Internationalization Process: The Case of US Food Service Sector
}

\author{
Valentina Della Corte $^{1} \&$ Giovanna Del Gaudio ${ }^{1}$ \\ ${ }^{1}$ Department of Economics Management, University of Naples Federico II, Italy \\ Correspondence: Valentina Della Corte, Department of Economics Management, University of Naples Federico \\ II, Italy. E-mail: valentina.dellacorte@unina.it
}

Received: March 1, 2016

Accepted: April 21, 2016

Online Published: May 22, 2016

doi:10.5539/ijbm.v11n6p205

URL: http://dx.doi.org/10.5539/ijbm.v11n6p205

\begin{abstract}
This paper aims at exploring the link between internationalization strategies and local identity. More precisely, this study analyzes how firms manage this relationship, understanding if a firm can express the local identity and to what extent this latter can be extended through without jeopardizing the essential soul of its products/services.

The analysis is developed according to a double level that includes the recognition of both distinctive resources and competences and the specific relational capabilities necessary in the internationalization process. Furthermore, the strength of this paper is represented by the examination of different types of firms (single location full-service restaurants, chain restaurants and fast food restaurants) operating in the food service sector.
\end{abstract}

Keywords: internationalization, relational capabilities, identity-making capabilities, food service sector

\section{Introduction}

\subsection{Introduce the Problem}

Internationalization is a process that can be either incremental or rapid and consists of pursuing foreign opportunities. The adoption of this strategy allows either catching or creating opportunities that lead to firm's growth in terms of business's expansion, new markets and profits.

This article sheds light on the internationalization process, with regard to the match between relational capabilities and distinctive resources and competences, both theoretically and empirically.

From a theoretical point of view, through the analysis of the main models developed by the literature on internationalization strategies, we propose a resource-based view that takes into account the overall set of capabilities (both identity-making and relational) an international firm has to possess in order to compete successfully. The focus is not just on firm-specific capabilities but also on those capabilities that express a profound link with the territory where the firm has been originally set and developed. In different activities, both in manufacturing and in service industry, some local factors become strategic for the firm and the whole area's competitiveness. In such case, for most of the identity-making resource-based firms, international strategies have to be conceived and implemented carefully in order not to lose the core factors of actual competitiveness.

Specifically, this paper seeks to address three interrelated questions:

RQ1: In the international capabilities construction, are both identity-making and relational capabilities relevant?

RQ2: Do these kinds of capabilities influence differently the internationalization process, generating different strategic paths?

RQ 3: Is there any risk of loosing identity-based strengths in the internationalization process?

For this reason, the empirical analysis explores the internationalization strategic patterns and behaviours of US firms in the food service sector.

Indeed, the internationalization of food firms in general and, more specifically, of the restaurants represents an opportunity for the economic growth of the territory. These firms, for several aspects (the cuisine rather than the ingredients, the management style, the origins of the personnel and their more or less peculiarly local approach) recall local identity. Moreover, restaurants are also considered as part of the services that are part of tourist offer 
in destinations (Della Corte, 2009; 2013), being part of the so-called "amenities" that contribute to favour a good perception of local offer. Considering the multiplicity of restaurants' formula, it is worth to wonder whether differences exist in terms of strategic choices regarding the internationalization of these firms and if in the internationalization it is difficult to preserve the identity-based factors, typical of the country of origin. The empirical section of this study analyses whether and to what extent single location full-service restaurants, chain restaurants and fast food restaurants tend to internationalize, the reasons underpinning such choice and if identity-making factors are kept or compromised in this process.

The article is organized as follows: first, we discuss the extant literature on internationalization, identifying the referring theoretical models. Within these, we adopt a new model on internationalization that takes into account different strategic factors. Next, we introduce the methodology and present the results thus getting to their theoretical interpretation and discussion. Finally we get to the main limits, the conclusions and highlight possible hints for future research.

\subsection{Literature Review}

Right from the early Eighties (Nelson \& Winter, 1982) some studies (Barney, 1991; Kogut \& Zander, 1993) have been conceiving internationalization as the expansion in new markets as well as the acquisition of foreign market knowledge (Khalid \& Larimo, 2012). Therefore, the entry into new markets has been seen (Helfat \& Leiberman, 2002; Zollo \& Winter, 2002) as a way through which this knowledge is used and combined with other factors.

Literature on internationalization has focused the attention on models that explain the internationalization process, in terms of essential components and relative interplay for the deployment of such process. The main models proposed by the referring literature are numerous but, according to the purposes and the issues of this research, we particularly take into account the Uppsala Model (U-Model-Johanson \& Vahlne, 1977), the Innovation Model (I-Model-Andersen, 1993; Gankema et al., 2000), the Knowledge-based model (Kalinic \& Forza, 2012, Mejri \& Umemoto, 2010), the born global model (Kalinic \& Forza, 2012), the International entrepreneurship conceptual model (Ruzzier, Hisrich, \& Antoncic 2006) and the International resource-based model (Della Corte, 2014) (Note 1).

The complexity of the $U$-model is demonstrated by the fact that it is shaped by an overlapping of different theories: the behavioral theories (Cyert \& March, 1963), the resource-based theory (Penrose, 1959; Barney, 1991) and the foreign investment theory (Aharoni, 1966).

The bidding agent of these complementary theories is the "business network perspective" that is at the basis of the U-Model. Indeed, each theory is explained in the light of an internationalization process that depends on the firm's bargaining power and on its managing network's relationships (Musteen et al., 2014), based on the certainty that network resources help overcoming the critical factors of internationalization (Kiss \& Danis, 2010).

The recall of the resource-based theory is linked to the vision that the resources available and/or activated at the network level can favor and sustain the internationalization process of the single firm. This network can be shaped either by local or foreign partners and it is conceived as a relational network that can be exploited in order to acquire market knowledge as well as new resources and competences.

The internationalization process needs not only the resource-based perspective: an entrepreneurial and/or managerial aptitude (Gimeno et al., 1997; Naldi et al., 2015) towards international expansion is necessary. This is the reason why the U-Model embraces the behavioral theories. The specific decision to internationalize is connected with both rational motivations (Cyert \& March, 1963) and strategic, tactical, and operational objectives (i.e. home market saturation, search of new market opportunities, lack for new ways of doing business, strategic renewal or a better employ of the already available resources and competences - Della Corte, 2014).

Finally, the foreign investment theory is conceived in the light of the degree of uncertainty that pushes firms to catch opportunities outside domestic markets.

Thus the U-model views the internationalization as "a gradual acquisition, integration and use of knowledge about foreign markets and operations and a successively increasing commitment to foreign markets" (Gankema et al., 2000, p. 16).

As regards this model, however, it is possible to outline that it has been criticized as too much behavioral and descriptive (Johanson \& Vahlne, 1977, 2009); in addition, the validity of this model has not been sufficiently tested (Hadjikhani, 1997). According to Axinn and Matthyssens, 2002, the U-model does not encompasses "hybrid entry modes". These authors also claim the necessity of an overlap between political, managerial and organizational mechanisms that act upon internationalization process. Finally, the learning component is 
conceived according to a narrow vision (Forsgren, 2002): the experiential learning contemplated in the U-model does not fit with the concept of high tech market, where the high speed requires fast changes.

The second "gradual" model is the Innovation-model (I-model) that supposes that internationalization is the output of innovative processes (Rao \& Naidu, 1992). The critical point of this model is that it is exclusively focused on export activities, considering three separate stages of internationalization (pre-export stage, early stage and advanced stage).

The I-model assumes that a company, originally, operates in the home market (Cavusgil, 1980) and after ripens the idea to export (pre-export stage). If this idea can be effectively carried out, the firm lives a pre-export stage with a first analysis and choice of the most appropriate markets where to operate. After this phase, the firm starts its internationalization process through export activities (early stage of export). What is important to underline is that the selected markets have socio-psychological characteristics similar to the home markets. The last phase concerns the growth (advanced stage) in terms of served markets and reached sales' volumes.

This approach has been criticized as vague in theoretical terms (Ruzzier et al., 2006): it does not offer practical insights and implication; hence it does not represent an efficient tool for managerial purposes. Besides, the "demarcation criteria" for the different stages of internationalization are not clear (Miesenbock, 1988; Andersen, 1993)

There are other common limits for both U-model and I-model (Della Corte, 2014):

1. They are static models (Leonidou \& Katsikeas, 1996) while the dynamic process of internationalization needs dynamic models;

2. They do not consider the environmental factors (Melin, 1992) that can accelerate and/or threaten the success of the internationalization itself;

3. They do not explicitly specify the type of governance: both theoretical and empirical works on U-model and I-model do not focus their attention on different types of governance which can differently affect the process.

Another model is the knowledge-based model (Kalinic \& Forza, 2012; Mejri \& Umemoto 2010), that encloses three internationalization phases (pre-internationalization, novel internationalizing, experienced internationalizing phase) and four kinds of knowledge (market knowledge, experiential knowledge, cultural knowledge and entrepreneurial knowledge).

Market knowledge refers to all those information concerning the market, in terms of size and characteristics, the main and secondary competitors and the political and legal environment. The acquisition of this knowledge depends on the ownership of absorptive capacity of both exogenous and endogenous factors (Laursen \& Salter, 2006). Moreover, the experiential knowledge resides at the heart of this model.

As regards the experiential knowledge, this includes the already acquired knowledge because the firm already operates in the local market, as well as the network knowledge is linked to the vision of the network as an entity that can be exploited in terms and business relationships.

With reference to cultural knowledge, it is "the knowledge of values, manners, and ways of thinking of people in that market” (Mejri \& Umemoto, 2010, p. 164).

The entrepreneurial knowledge is linked to the ability of exploring and exploiting opportunities. The entrepreneurial internationalization can be, indeed, the result of the deployment of the entrepreneur's capabilities related to the phase of both exploration and exploitation as well as to entrepreneurial behaviours (Li et al., 2015) in innovativeness, risk taking, and proactiveness.

Actually, starting from the assumption that decision making inside the firm is based on rational agents' behaviors that act entrepreneurially by creating/catching opportunities, the entrepreneurial capabilities emerge when the creation of strategic options (Klingebiel, 2012), such as internationalization, can be pursued.

On one side, the entrepreneurial investigation on new opportunities and the search for new knowledge, resources and competences belong to the exploration sphere. On the other side, all these behaviors must then overlap with entrepreneurial exploitation behaviors.

With reference to the Knowledge-Based Model, there are some limits connected the outlying of specific stages of internationalization and the lack of explanation on how the sedimented experiential knowledge influence the business relationships.

As regards the Five/Five Stages Model (Jansson \& Sandberg, 2008), this provides the existence of a firm that is already operating in the domestic market. The first phase is the pre-relationship stage that aims at activating 
relationships in order to after start an internationalization process; the second stage (early stage) is more intense than the first one since it views the effective resource sharing within the network. Then, there are the initial stages and the development stage where the resource sharing, the trust among the partners of the network and the confidence related to the new markets and consumers increase. Finally, the last stage is characterized not only by long-term relationships also by a shared vision among the partners of the network.

The above-cited models describe a gradual internationalization process.

In this case, the international entrepreneurship conceptual model (Ruzzier, Hisrich, \& Antoncic 2006) is shaped by different dimensions, such as product, time, mode and market. The international performance of the company measured in terms of profits and growth in sales, and, finally, by some antecedents ( $\mathrm{Li}$ et al., 2015) of internationalization are the specific entrepreneurial characteristics, human and social capital, firm's characteristics, environment.

However, the main limit concerns the measurement of the human capital dimension. The same authors (Ruzzier et al., 2007) underline the limitation of the study "includes the high interrelatedness of the human capital dimensions we measured (e.g. international business skills and international orientation- Covin \& Miller, 2014) and possible informant bias".

More recently, some scholars (Kalinic \& Forza, 2012) have developed the "born global" model while others have hypothesized the existence of hybrid models in which both gradual and rapid growths can take place (Ruzzier et al., 2006). This latter model is based on some dimensions (mode, market, product and time), showing how firms can activate the internationalization process after years or directly operating as global. The born global model (Kalinic \& Forza, 2012) deepens its roots in the resource-based theory (Barney, 1991), the dynamic capabilities approach (Sapienza, \& Davidsson, 2006), the Network approach (Oviatt \& McDougall, 2005) and the organizational learning approaches (Oviatt \& McDougall, 2005).

This view explains a rapid internationalization process realized by "born global" or "born-again global" firms (Kalinic \& Forza, 2012). A fast growth also depends on the sector where the firm operates (Rialp et al., 2005). Some authors indicate that sectors like manufacturing are more prone to internationalization (Rialp et al., 2005).

However, the born global model is limited in its lack of been tested empirically also on unsuccessful cases: this would allow having a control group" (Kalinic \& Forza, 2012).

From this study, taking into account both strengths and weaknesses of the above cited models, a clear gap emerges since scholars do not develop a unique model that can be useful for the study of both gradual and rapid internationalization.

This is the reason why we decided to embrace e more complex model (Della Corte, 2014) that recalls the concept of innovative capabilities able to create and reinforce new assets through entrepreneurial creativity. In this context, the role of the entrepreneur comes back according to the Schumpeterian (1934) view, sharing the idea that the entrepreneur is a figure who drives the innovation and leads to technological change, able to leverage information technology (Todd \& Javalgi, 2007; Keen \& Wu, 2011).

Thus, the concept of innovation perfectly joins the internationalization process since an entrepreneur can have "growth aspirations" (Devece et al., 2011) in exploring/exploiting opportunities outside firm's boundaries.

Furthermore, the specific recall of innovation capabilities concerns, as Amsdenand and Hikino (1994) underline, the necessity to own these resources in order to successfully compete and perform in turbulent and uncertain contexts. Moreover, strategic resources can reside in the heart of the organization or/and in the figure of the entrepreneur as well as be nested within or outside the firm (Lavie, 2006). This network perspective leads to consider also the relational capabilities (Nahapiet \& Ghoshal, 1998), fundamental for the access to information on foreign markets.

Although previous models (the U-model, the international entrepreneurship conceptual model, the integrated framework of the enablers of a non-sequential internationalization, the Five/Five Stages Model and the born global model) emphasize the importance of the network, there is not a clear link with relational managerial capabilities that help addressing challenges and opportunities concerning the internationalization.

Besides, the up to now developed literature does not consider if the critical aspect of identity-based resources and competences has an impact on internationalization strategies. In addition, the entrance in new markets and their relative knowledge are linked by a bridge consisting of a competence and relational-based approach related to internationalization. The relational capabilities (Dyer \& Singh, 1998) are broadly considered fundamental in purchasing international business (Pagano, 2009). 


\subsection{Theoretical Framework}

Considering the limits of the previous approaches, a new model (Della Corte, 2014) has been developed in order to show how born global and non-born global firms can move towards the internationalization. This model is mainly based on resource-based theory and more specifically on dynamic capabilities and competences in a networking perspective (Augier \& Teece, 2007).

Drawing inspiration from previous studies (Ruzzier et al., 2006), it is built upon two main variables: one is the direction of development, that can be either internal, external or direct (this latter is the case of born global firms) (Figure 1); the other indicates the places where the resources reside (internal, external or network level). Some specific capabilities (technical and operative capabilities, entrepreneurial capabilities, innovative capabilities, relational capabilities) and other factors (history, brand image, knowledge, governance structure) are considered as issues to analyze. Therefore, in this framework the identity-making resources are contemplated as a specific component of the overall set of resources and competences that are strategic in internationalization strategies.

As regards the entrepreneurial capabilities, the above-discussed contents become richer with the addition of active relationship between the firm and its territory. This refers to the component of entrepreneurial capabilities in addressing local opportunities and challenges (Scott, Gibbons, \& Coughlan, 2010) in the optic of social sustainability, i.e. trying to involve the local community and to use local resources. It also refers to catch foreign opportunities and exploit economies of scales (Hennart, 2007).

With reference to knowledge, it concentrates on networking knowledge, entrepreneurial knowledge and cultural and market knowledge as the previous knowledge-based model underlines.

Finally, previous models have not explicitly linked the components of "reputation" and "brand image" to internationalization. The classical stage models (Cassiman \& Golovko, 2011) describe the last phase as a stage where the firm achieves increases in sales' volumes without studying how reputation and brand image in foreign markets act upon this increase.

This model has some strengths. Firstly, the identification and the classification of resources and competences allow understanding that the internationalization process is based on different aspects that can be summarised into some specific macro categories, such as: the resources mainly connected with the territory, the network resources and the knowledge that is related with the history of the territory and the cultural identity.

According to this classification, it is possible to distinguish the identity-making capabilities from the relational ones.

The identity making capabilities are connected with the identity aspects of the firms, the link with the territory (local resources), the level of innovation in offering of products/services in foreign markets. On the other side, the deployment of these capabilities requires the ability of the entrepreneur as well as of the top managers to express the firm's identity and to communicate this latter to customers of foreign markets and to other stakeholders that operate in international markets (Autio et al., 2011). Particularly, this local identity expresses itself mainly through food traditions, as in the case of restaurant firms. Firms that internationalize can have two kinds of challenges, related to local identity, during their strategic choices. The first refers to the use and exploitation of local resources, related to the territory of origin, in foreign markets. The second regards the glocality-based perspective (Abecassis-Moedas et al., 2012), that is deployed when firms provide taylor-made solutions, including in their offerings some peculiarities of the cultural dimension of the specific market.

All these aspects are at the base of the firm's identity formation. The capabilities to build and exploit these elements govern the process that leverages the identity aspects. Knowledge can also be associated with some identity traits that belong to the external boundaries of the firm. Indeed, the knowledge of territory's culture and history can be used and combined with all those typical aspects of the firm.

The capabilities in creating, developing and maintaining the identity can generate an enhancement to access in both domestic and foreign markets.

As regards the relational capabilities, they allow developing an international process. The inter-firm relationships are of fundamental importance for the global growth. Within international process in social and in the political environment, relationships' building supports the internationalization process (Darkow et al., 2015).

The cooperative behaviours, either vertical, horizontal or in the network, are the outcome of relational capabilities both at firm and systemic level.

The relational capital (Dyer \& Singh, 1998) and the other organizational capabilities can explain the internationalization process since their interplay can give rise to internationalization. 
The International resource-based model shows a link between the relational capabilities and the history of the firm. The culture and the history of the firm can, indeed, influence the result as well as the success of activated partnerships (Della Corte, 2014).

Within the history variable, governance structure is another fundamental element to consider within the internationalization process (Chen, 2011; Arregle et al., 2011; Barroso et al., 2011; Filatotchev \& Wright, 2011). The internationalization recalls the topic of firm's governance since this latter can determine the firm's ability in the resource access in foreign markets (Arregle et al., 2011; Melin, 1992; Tihany et al, 2003). The process changes a lot, if we consider an entrepreneurial firm in face of a managerial one. Big firms, with widespread ownership and a managament staff highly committed on internationalization can more easily - even if not always - start their internationalization strategies very soon. For smaller, singly owned or family owned firms, the process can be different and slower. Of course this is not the rule but it is obvious that such process requires specific capabilities, that often bigger firms have more resources to invest on.

Governance structure is shaped by both the ownership and the board (Rediker \& Seth, 1995; Brunninge et al., 2007). The behavioral theory demonstrates that internationalization is the result of a process wanted by the top management (Chen, 2011) or by someone who is the firm's decision maker. The governance structure as well as the governance mechanisms (i.e. independent director, foreign institutional investors, outside CEO, etc.) influence the internationalization relationship (Chen, 2011).

The internationalization often requires the presence of external parties that acts as "catalyst" or "resource providers" in the governance (Arregle et al., 2011). Literature on the issue empathizes the necessity of these external parties, especially in the family-based firms. This topic is strongly debated in literature since external parties may create "conflicts between family and nonfamily members" (Arregle et al., 2011), representing a threat because there could be "other voices at the table" (Sirmon et al., 2008) for the strategic decisions. However, for smaller enterprises the use of external resources and relationships is of strategic importance in this kind of firms since they allow to undertake the decision of internationalization (Arregle et al., 2011).

Another relevant factor, in internationalization strategies, is the consideration of the cultural factor as extremely influential in front of the match/mismatch between the host national culture and the foreign culture. Cultural elements can influence the process in two directions:

- In maintaining the cultural identity of the business, of the products/services, of the leadership and human resource management style: this variable can be determinant because some firms, owing to the core competencies that result strictly bound to their territory, up to express the territorial identity through their services or products, have the problem of keeping this specificity even in internationalization;

- Connected to the first one, the question is how does the firm's culture has to interact with the culture of the countries where it internationalize, without however losing its identity. In other words, the local culture of the countries of entry has to be considered, trying to understand if and to what extent to satisfy some specific local needs without compromising their own identity.

Indeed, for some firms, one of the most important prerequisite in the internationalization choice is to be both physically and culturally close to their domestic markets (Andersen, 1993; Johanson \& Vahlne, 1977). Distant markets are, in some cases, reached in the second step of the internationalization exactly because firms have to understand there the cultural matrix and the related entry strategy. There are also some important costs to sustain, connected with learning a new culture and local adaption costs (Contractor, 2007).

Hence, there is, on one side, the national culture of the firm while, on the other, the cultural distance between the firm's country origin and the culture of the foreign market. Indeed, the national culture can influence "the decision of internationalization, but also the choice of host countries, the selection of entry mode strategies, the internationalized firms' organizational design, transfer of knowledge and management of human resources, as well as the final performance of the process" (Lòpez-Duarte et al., 2015 p. 7). Also firm size (i.e., micro, small and medium, big) can influence the mode of internationalization and its related risk (Anwar, 2015).

The cultural aspect also represents the identity of the firm. Since the integration with the hosting culture is necessary as well as unavoidable, the firm must own the capability of maintaining and not losing its cultural integrity. If this latter sentence is true, on the other side, firms increasingly know that they have to match the foreign culture with a vision of integration and revaluation not only of the organizational aspects but also of the offered product/service. There must be the balance between friendly domestic and international environment (Peng et al., 2008). 


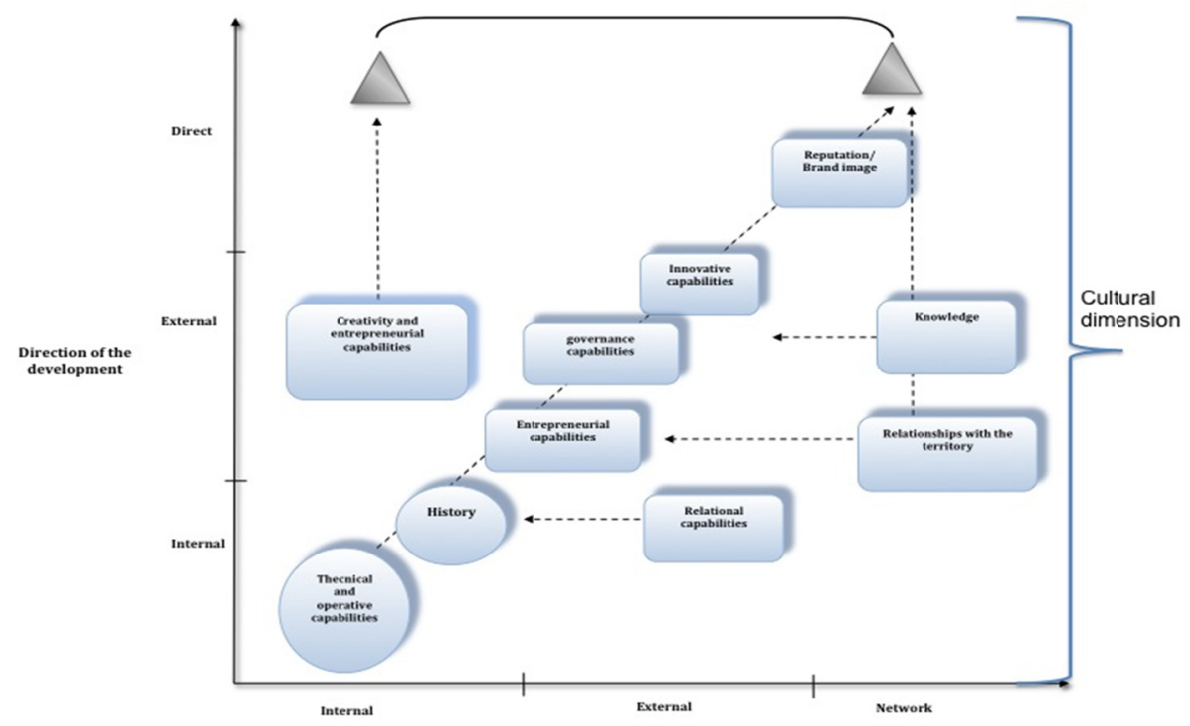

Figure 1. Direction and roots of resources

Source: Our elaboration from Della Corte, 2014.

The novelty of this model is that it does not focus on the process but rather on the sources of internationalization. This is a new approach to internationalization, based on the analysis of the its sources and contents, rather than on the process that, as seen can take place in different ways, with different phases. This view, instead, better helps finding out the main drivers for the firm in implementing internationalization strategies.

The originality of this model, therefore, lies in the identification of specific resources and competences both identity-making (such as technical and operational capabilities, the history and the reputation/brand image, entrepreneurial capabilities, creativity, cultural elements, governance capabilities) and relational (relational capabilities). Moreover, there are other transversal components regarding the entrepreneurial creativity and the relationships with the territory. The first one refers to the degree of innovation and to how the entrepreneur addresses local opportunities and challenges (Scott, Gibbons, \& Coughlan, 2010) according to a creative approach. The second one can assume different meanings that firstly regard the link with the original territory in terms of use of local resources and the recall of the territorial identity. The second meaning can be related to the local community employment of the international countries or with a different offer, which joins the local styles.

Another point of novelty resides in the fact that governance capabilities are contemplated in this model. First of all, the composition and function of the board of directors (Chen, 2011) are important both for the decision to internationalize and for the development of business activities in foreign markets. According to a relational perspective, the demographic composition of the board can also influence the internationalization (Zahra et al., 2007). Hence, the governance structure is critical for the access to resources for internationalization (Arregle et al., 2012).

Sharing the perspective sprung out from the literature, we believe in the existence of both non-born global and born global firms. It is therefore interesting to verify if the competencies and the capabilities able to generate competitiveness can vary in the two different contexts (gradual internationalization versus born global firms) and if different typologies of firms can have various behaviours towards internationalization.

What is also important to underline is the link between internationalization and restaurant firms. Indeed, while research in the food service sector has analysed customer service improvement (Dickson, 2015; Zhang et al., 2013), quality (Seaman \& Eves, 2006; Eves \& Dervisi, 2005) and marketing activities (Powers \& Barrows, 2009; Rathmell, 1974) or innovation (Rodgers, 2007, 2008), little is known about the strategic choices referring to internationalization. The current paper aims at exploring the different strategic choices three clusters: single location of full-service restaurants, chain restaurants and fast food restaurants. Although there is a recognition of the importance of internationalization strategies (Wrigley, 2000) due to fact that it is possible to exploit economies of scale or geographic scope (Kogut, 1985), that generate value in terms of ROI and ROS (Vernon, 1971), actually not all the food service firms tend to internationalize. 
Starting from the fact that the food service sector is related to the service sector and "service cannot be exported" (Erramilli, 1990), there are, indeed, numerous challenges to face (Samiee, 1999) as well the availability of specific resources and competences in order to invest in other countries. One of the first difficulties is linked to the decision of entry modes (i.e, contractual entry, licensing or franchising, and foreign direct investment Erramilli, 1990) and to the nature of specific peculiarities of each typology of food service firms.

\section{Method}

In this paper, we focus on the role of both identity-making and relational capabilities, taking into account the relative interactions and examining to what extent they can favor internationalization process. In particular, the analysis is referred to the strategic behaviors concerning the internationalization of US chain restaurants, single location full-service restaurants and fast foods.

In order to explore these research issues, the paper uses an in-depth multiple case studies analysis (Eisenhardt, 1989; Yin, 2003).

According to Aarikka-Stenroos and Sandberg (2012, p. 201) multiple case studies "allow rich description and comparison" and to proceed with a cross-case comparisons (Eisenhardt, 1989). Furthermore, the case study methodology is able to capture contextual richness and complexity of research issues (Yin, 2003). Each case has to be studied as a single case (replication).

According to Aaboen et al. (2012, p. 236) multiple case studies "facilitate identifying and analyzing particular patterns in certain processes and explaining differences across cases by contrasting them to each other". This kind of methodology is suitable for theory development (Aaboen et al., 2012).

Furthermore, Eisenhardt and Graebner (2007) underline that multiple cases study approach is an effective vehicle to obtain new knowledge about a specific phenomenon since it allows understanding the research issue from different standpoints.

More precisely, we study US chain restaurants, single location full-service restaurants and fast foods cases according to an analytical approach and a process perspective (Langley, 1999; Williams et al., 2014). This latters refers to the research procedure. The steps, shaping this process (sampling, data triangulation data collection and discussion), constitute the key features for supporting the research.

This method of research allows to understand whether and how decisions of internationalization evolve over time.

This paper uses a mix that encompasses the exploitation of primary and secondary sources of data aiming at understanding if differences in internationalization choices exist and if there are specific capabilities that can generate and support the process.

The research process follows a precise path that is constituted by the sampling, data triangulation data collection and discussion (Williams et al., 2014).

As regards the sampling, the cases of chain restaurants, single location full-service restaurants and fast foods were selected using different industry databases. These latters were used to identify restaurants that started international strategies. These databases offered some advantage for the purposes of our work's poin of view, as they identy some variables that can be compared for each case. Finally, we excluded from our analysis cases that were not comparable with those that proceed with internationalization startegies. As this paper was primarily interested in the US context, we also excluded cases of other countries.

After data were triangulated. This was useful to identify distortions in each data collection in terms of source and method in order to utilize other data if the previous were not correct.

The purpose of data collection was to catch some information on restaurant industry performance, on market share, referring consumers and international growth and to identify the resources and competences exploited by the firms during the internationalization process. In addition, information on resource and competences as well as on other strategic factors were collected in order to, finally, understand the main reasons of internationalization and not internationalization. Different data regarded industry databases, company reports and press releases.

Finally, the discussion showed the main results, comparing the selected cases and highlighting the different behaviours in terms of internationalization.

\section{Discussion}

Restaurant firms in the United States although, on one side, show steady values for the state health, on the other, 
reveal a general and solid expansion with their performance. Figure 2, indeed, shows the restaurant industry performance index in the United States from 2011 to 2015, by month. This graph points out that values are more than or around 100. These are synonymous of growth. Particularly, the situation in the first months of 2015 reports higher values compared with previous years. This fact is comforting, since the restaurant industry performance index is expression of store sales, traffic, labor, employees, capital expenditures and business conditions (National Restaurant Association, 2015).

In general, this graph confirms the good state of health of the US restaurant industry.

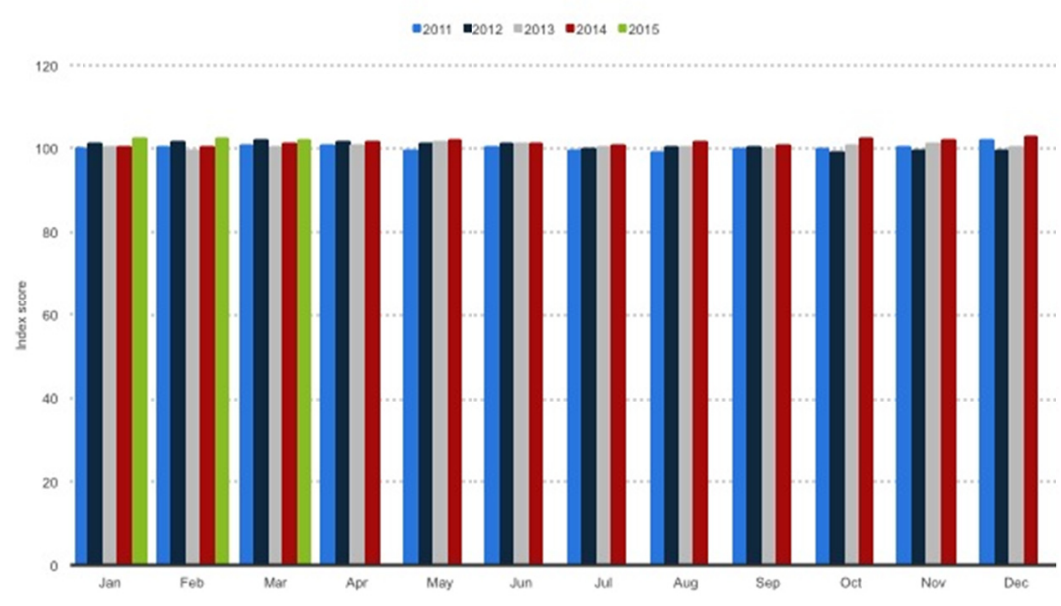

Figure 2. Restaurant industry performance index in the United States

Source: National Restaurant Association, 2015

Table 1 and 2 show some data and hints on US chain restaurants, single location full-service restaurants and fast foods.

As regards the whole restaurant industry, some indicators demonstrate an increase. For example, between 2011 and 2014, the number of restaurants raises from 611,566 to 630, 964 (NDP Group Survey, 2015) and the sales amount to 659,31 billion U.S. dollars in 2013. Furthermore, it is very interesting to underline the forecast, referring to the revenue of the fast food restaurants, with 210.22 billion U.S. dollars in 2018.

Table 1. Hints on US restaurants

\begin{tabular}{|c|c|c|c|c|}
\hline Year 2014 & Chain restaurants & $\begin{array}{l}\text { Single location } \\
\text { restaurants }\end{array}$ & full-service & Fast foods \\
\hline Revenue & $\$ 97.2$ bn & $\$ 159,4$ bn & & $\$ 207,8$ bn \\
\hline Annual growth 10-15 & $2.4 \%$ & $2,4 \%$ & & $1,2 \%$ \\
\hline Profit & $\$ 6,6$ bn & $\$ 9,9$ bn & & $\$ 10,6$ bn \\
\hline Wages & $\$ 31,2$ bn & $\$ 55,2$ bn & & $\$ 51,6$ bn \\
\hline Business & 782 & 247,860 & & 152,651 \\
\hline
\end{tabular}

Source: IbisWorld, 2015a, b, c.

Table 2. Hints on market share

\begin{tabular}{llll}
\hline & Chain restaurants & Single location full-service restaurants & Fast foods \\
\hline Market share & Dine Equity $8.0 \%$ & There are no major players in this industry & McDonald's Corporation $17 \%$ \\
& Darden Restaurants $6.8 \%$ & & Yum! Brands Inc. $10.8 \%$ \\
& & & Subway $6.7 \%$ \\
& & Wendy's Company $4.4 \%$ \\
\hline
\end{tabular}


Looking at the international capabilities construction, it is important to understand the role of identity-making and relational capabilities and if these kinds of capabilities influence differently the internationalization process.

For the internationalization process of the chain restaurant, the role of relational capabilities is of fundamental importance for the entrance in the markets where the firms decide to operate as well as for later developments. Indeed, the entry can be carried out through agreements with local affiliated entities. This is the case of DineEquity Inc., which for the international expansion of its subsidiaries chooses this kind of entry option (Ihop, 2011) that also allows an international development of huge dimension.

The identity-making capabilities play a strategic role in the internationalization process. Actually, there are some aspects related to the firm's identity that have a predominant role in foreign markets. History, for example, gives a strong link with organizational identity. The success of the international strategies of Darden Restaurants inhabits in its centenary history that has not only generated trust according to a consumer perspective but also created a strong relationship between identity and the long-term reliability. On the other side, other elements that shape the sphere of organizational identity, such as the connection with the territory, lose ground in the international expansion.

For the single location full-service restaurants, internationalization is "non-existent" since firms operating in this kind of industry do not pursue this strategic choice as growth opportunity.

From these first reflections, it is possible to deduce the main motivations of non-internationalization. Firstly, relational capabilities are low and connected to an exclusive local growth. On the other side, it emerges a high degree of identity-making capabilities since that, in this typology of firm, "the food acts as a maker of cultural identity" (James, 2002, p. 78).

As regards the sources of internationalization process of US fast food restaurants, it is interesting to notice how and whether relational and identity-making capabilities interplay.

In the examined cases, the relational capabilities play a key role not only for the entrance in new markets but also for the growth in these countries. Indeed, fast food restaurants are in a mature stage also in the international markets.

For example, it is underlined that "McDonald's theory of international relation" is related not only to the way of entrance through a local network but, especially, to the exploitation of relationships for a sustainable development in the referring international markets.

"Partnering for success" is one of the main sentences of McDonalds. Indeed this company does not only look at partnerships for an international growth but, especially, for a sustainable international growth. Some examples can be the environmental defense fund, the international scientific advisory council, the animal welfare found, etc.

Indeed, with the same term "McDonaldization" is interpreted as the process by which the principles of the fast-food restaurant are coming to dominate more and more sectors of American society as well as the rest of the world" (Heer \& Penfold, 2003). In a first period, McDonald started to take the American standardized formula and carry it in foreign markets. This strategy was a failure since this did not encounter the needs of foreign customers. In a second period, indeed, McDonald changed its strategy, pointing the attention on the tastes and needs of the different domestic markets. For example, McDonald introduced in China the formula "Aunt and Uncle McDonald" since this market has a particular attention on family values.

Besides, the identity-making capabilities are critical for the success in international markets. On one hand, the history of the firm can be exploited since it allows a costumer's recognition of the brand, the values and the related products. On the other, aspects as the relationship with the original territory must be balanced with new aspects that also focus on the territories where the stores of these fast foods are located.

There is, indeed, a general tendency of the US fast foods to propose, on international markets, both the menu proposals of the American context and more local products that meet consumers' tastes and preferences and with national raw materials.

Hence, as regards the first research question "In the international capabilities construction, are both identity-making and relational capabilities relevant?", looking at international capabilities construction, we specifically question the role of identity-making and relational capabilities in order to understand whether and to what extent they are relevant. First of all, the answer comes out of the analysis of relational capabilities at different stages of internationalization. They are of fundamental and primary importance both in the early stage of internationalization and in the development phase. Within internationalization of restaurant firms, these 
represent the capabilities of a firm to search, select, activate and maintain strategic relationships on international market. Furthermore, these relational capabilities presume also the existence of knowledge recognition and exploitation capabilities. The existence of a relational network (such as suppliers, customers, local producers, etc.) is a necessary condition but not sufficient to gain any form of advantage both for fast foods and chain restaurants. For these firms, network exploitation means to sustain competitive advantage through the knowledge of the actors of the network that own higher knowledge on international markets and on specific foreign dynamics. For born global firms, relational capabilities are important for the operational phase of restaurant activities, as in the case row materials' suppliers. These kinds of relationships allow to use and capture the right relationships for the implementation of ordinary activities. Indeed, from the analysis it emerges that the born global firms show to be internally structured for global strategies without the need of a relational network to place the basis in international markets.

With reference to the identity-making capabilities, these are important, but the analysis highlights that not all the identity aspects are really and fully exploited. Although single location full-service restaurants exploit this kind of capabilities but they not internationalize, identity-making capabilities are under used by fast foods and chain restaurants.

Hence, from this analysis it emerges that relational capabilities are of primary importance while identity-making capabilities receive less attention by foods and chain restaurants during their process of internationalization.

To the second research question "Do these kinds of capabilities influence differently the internationalization process, generating different strategic paths?", that wonders if these kinds of capabilities influence differently the internationalization process, generating different strategic paths, a positive answer can be given. From this study, in fact, it comes out that these capabilities influence differently the internationalization process since they act on two different levels. Indeed, the relational capabilities are important from both a strategic and operational point of view, in the entrance as well as in the development/growth phase in the international markets. On the other side, the identity-making capabilities result essential in the firm-customer relationship, as they are able to build trust as well as satisfaction. These capabilities, in the cases of fast foods and chain restaurants, contribute to brand consolidation through contents linked with firm's identity. In this identity-making process, also culture plays a key role.

What comes out from the analysis is the fact that, until now, these kinds of capabilities do not catch and exploit well all the identity factors of the companies in their link with their originally territories.

From here, the answer at the third research question "Is there any risk of loosing identity-based strengths in the internationalization process?" comes out. The analysis shows that chain restaurants have sometimes links with the original territory when the concept of restaurant must express local identity in terms of service scape and dishes. Fast foods, on the other side, internationalize without links with the territory of origin except when these firms try to balance their menu with some proposals that take into account local products or dishes (of the foreign market). Hence, there are some risks of loosing identity-based strengths in the internationalization process.

Moreover, factors as the history and the link with the territory also expressed by local product used in the preparation of the dishes, show the ability to deploy the identity-making capabilities that are fully exploited at local level but not internationally.

Once understood how these kinds of capabilities interplay, it is important to get a sense of the actual framework of the state of internationalization of US fast foods, chain restaurants, and single location full-service restaurants.

The internationalization of fast foods can be defined as "innate", as it is contemplated in the long-term strategy. The objective referring to the adoption of this specific strategy is linked to the main motivation of long-term profitability. This means, "international sales represent an increasingly larger part of operators' total revenue" (Ibis World, 2015, p. 8). Nonetheless, this kind of expansion, on the other side, delimits the domestic growth.

The international openings represent one of the main features of this industry. The franchising formula, adopted by the major players, allows a better internationalization process.

The fact that the expansion of fast foods has become global requires not only organizational adaptation but also managing local customers' needs and taste.

For example, when McDonald's entered in China, the differentiation of the dishes in the menus compared to the universal and tradition offer has represented the willingness to adapt to the taste and behaviours of the new market. Moreover, the fact that China is a market where there is a high density of business people required, right from the first entrance, 24-hour restaurants and more McCafés. In the same direction, Yum! Brands, with its 
brands KFC and Pizza Hut, offers 24-hour service, home delivery and breakfasts in China. This chain points on the experiential component for Pizza Hut stores in China, including new options in the menu (i.e., wine and escargot). The cultural changes of Yum! Brands in China refers not only to the adaption to new tastes but also to the hiring of Chinese managers that deeply know the market, the economic and social context.

Furthermore, in Italy, where the culinary tradition denotes a high quality identity, McDonald's launched dedicated hamburgers under the brand "Mc Italy" realised with Italian products (i.e., Bresaola from Valtellina, Speck from Alto Adige, Parmigiano Reggiano) or activated 3 weeks co-marketing campaigns with Italia star chefs (i.e, Gualtiero Marchesi) to present new hamburgers.

Hence, major US franchised and chain food operators are making significant investments in international growth through franchised and company-owned operations. For example, in 2012, Yum International opened 1,976 restaurants across six continents, including 889 new restaurants in mainland China and 138 in India. Currently, about half of Domino's outlets are international stores. This is because the US (and other developed nations') fast food markets are in the mature stage of their industry' life cycle, which is limiting revenue, profit growth and investment returns. Changing consumer tastes and concerns about the nutritional value of fast food have also encouraged the shift toward emerging nations, characterized by high population, high income and growing middle class (IbisWorld, 2015). In fact, both McDonalds and Yum! brands, which are the major companies operating in the fast food market, earn about $60.0 \%$ of their sales overseas; about $40.0 \%$ of Burger King's sales derive from international markets and Subway earns about $30.0 \%$ of its sales outside of the US.

These cases demonstrate that, on one side, firm loose their identity-based strengths in the internationalization process but, on the other, they acquire local aspects of the foreign markets, considering the cultural dimension.

Also the governance structure helps implementing internationalization strategies. For example, McDonald's has a solid governance structure where relational capabilities come out since there is the existence of strong relationships between the Board, the management and the shareholders. The governance principles (integrity, fairness, diligence and ethical behaviour) are the base of the McDonald's governance model (McDonald's, 2009).

The underlying graphs show some information on US fast foods.

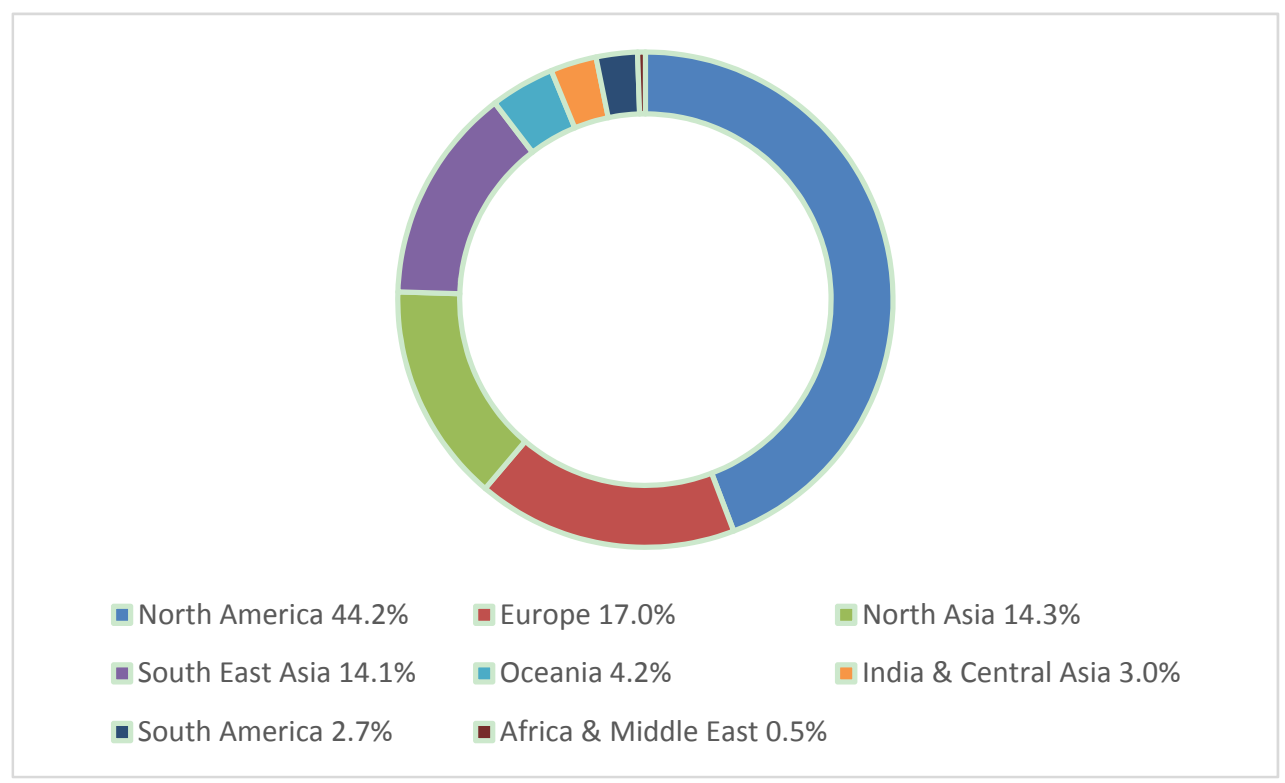

Figure 3. Business locations (revenue \%)

Source: Ibis World, 2015. 
Table 3. Some information on US fast foods

\begin{tabular}{ll}
\hline Information & Value \\
\hline Global consumer spending (average annual rate 2015-2020) & $3.5 \%$ \\
International growth - Major countries & Asia and the Middle East \\
$2015-2020$ & \\
Expected revenue 2015-2020 & annualized rate of 3.8\% to \\
& $\$ 693.5$ billion \\
Number of establishments & average $0.6 \%$ per year to 857,458 locations \\
\hline
\end{tabular}

Source: IbisWorld, 2015d.

Table 4. US fast foods revenue outlook

\begin{tabular}{lll}
\hline Year & Revenue $\$$ million & Growth \% \\
\hline 2016 & $600,000.0$ & 4.5 \\
2017 & $623,600.0$ & 3.9 \\
2018 & $645,600.0$ & 3.5 \\
2019 & $676,588.8$ & 4.8 \\
2020 & $693,503.5$ & 2.5 \\
2021 & $710,418.2$ & 2.4 \\
\hline
\end{tabular}

Source: Ibis World, 2015d.

Chain restaurants have viewed a slow growth in the last five years. This industry is passing a restructuring since the domestic development is moderate and firms start to look or already operates in overseas markets. The chain restaurants are acquiring a huge international presence and their revenues are increasing. What is important to underline is the fact that not all the firms internationalize. In fact, they are US-owned and earn the majority of their sales from domestic activities (Ibis World, 2015). Nonetheless, some large chain and franchised restaurant operators (i.e. Brinker International and Dine Equity Inc.) have international operations.

While a wide portion of firms continues to operate in the domestic market, the major players of this industry have already realized strategic choices referring to internationalization, observing a real enhancement in revenues and earnings. Since direct competition is lower in many emerging and high-growth countries, the international trend is likely to continue. In addition, some countries, like China, provide the added attraction of significantly expanding middle-income households (Ibis World, 2015).

Table 5. US Chain restaurants revenue outlook

\begin{tabular}{lll}
\hline Year & Revenue \$ million & Growth \% \\
\hline 2016 & $99,005.5$ & 1.8 \\
2017 & $99,659.1$ & 0.7 \\
2018 & $101,397.5$ & 1.7 \\
2019 & $103,438.0$ & 2.0 \\
2020 & $105,523.8$ & 2.0 \\
2021 & $107,287.3$ & 1.7 \\
\hline
\end{tabular}

Source: IbisWorld, 2015.

Also for the chain restaurants, the cultural element is of fundamental importance. For example, Darden Restaurants, in order to enter in the Asiatic market, signed an agreement in 2013, with Secret Recipe, the leading restaurant operator in this market. With this area-development agreement, some restaurants opened in Malaysia under the brands Darden's Olive Garden and LongHorn Stakehouse. Similar agreements have been signed in Middle East and Latin America. These partnerships with local and leading operators underline the necessity to be on track with cultural and taste differences, restaurant system, marketing, restaurant design and taylor-made 
trainings (Ibis World, 2015a).

As regards single location full-service restaurants, their strength resides in the fact that, nowadays, the customers' requests depend on more local food since, in this kind of industry, "globalism has made local more important" (Quelch \& Jocz, 2012). In fact, the healthy and eco-conscious trend lead up firms to expand the number of healthy options on their menus and source more of their ingredients from local providers. In the last years, the firms operating in this market have faced some significant challenges: the main external threat has been the growing number of chain restaurants with increasingly diverse menus. In addition, the working time of the average is increasing and many do not have time to sit down for a meal at a full-service restaurant (Ibis World, 2015).

The firms, belonging to this kind of industry, tend not to internationalize: the industry consists largely of small business owners that serve the domestic market.

There are no major players in this market; the majority of the single location full-service restaurants is located in Asia $-25.5 \%$, while the American restaurants represent the $20.2 \%$ of the world's product and service segmentation (Ibis World, 2015).

Table 6. US single location full-service restaurants revenue outlook

\begin{tabular}{lll}
\hline Year & Revenue \$ million & Growth \% \\
\hline 2015 & $163,586.0$ & 2.6 \\
2016 & $168,002.8$ & 2.7 \\
2017 & $171,698.8$ & 2.2 \\
2018 & $176,849.8$ & 3.0 \\
2019 & $180,740.5$ & 2.2 \\
2020 & $184,536.0$ & 2.1 \\
\hline
\end{tabular}

Source: IbisWorld, 2015.

From this analysis, it comes out that different internationalization strategic patterns and behaviours exist among firms operating in the same sector. Indeed, fast food restaurants are prone to internationalization and, often, they are born global firm. The internationalization of chain restaurants may depend on the dimension of the firm. Big players realize internationalization strategy while smaller firms continue their growth at national level. Table 7 summarizes the main motivation referring to internationalization or non-existent internationalization.

Table 7. Internationalization and not internationalization: main reasons

\begin{tabular}{|c|c|c|c|}
\hline & Chain restaurants & $\begin{array}{l}\text { Single location full-service } \\
\text { restaurants }\end{array}$ & Fast Foods \\
\hline Reasons & $\begin{array}{l}\text { - Mature Stage of this industry's life } \\
\text { cycle in the domestic market } \\
\text { - changes in customer profiles and } \\
\text { tastes }\end{array}$ & $\begin{array}{l}\text { - No international trade } \\
\text { - small business owners } \\
\text { - service-based nature }\end{array}$ & $\begin{array}{l}\text { - slow domestic growth } \\
\text { - saturated domestic market } \\
\text { - stagnant domestic profit } \\
\text { - changes in customer profiles } \\
\text { and tastes } \\
\text { - Mature Stage of this industry's } \\
\text { life cycle. }\end{array}$ \\
\hline
\end{tabular}

Source: IbisWorld, 2015a, b, c.

Figure 4 shows the main sources of the internationalization process for both chain restaurants and fast foods, helps in the understanding on how these two clusters operate on the international markets. From the graph, the analysis of single location full-service restaurants is excluded because internationalization is, in this cluster, non-existent. Furthermore, governance capabilities are not considered in this figure since they require a firm level analysis rather than a cluster analysis. 


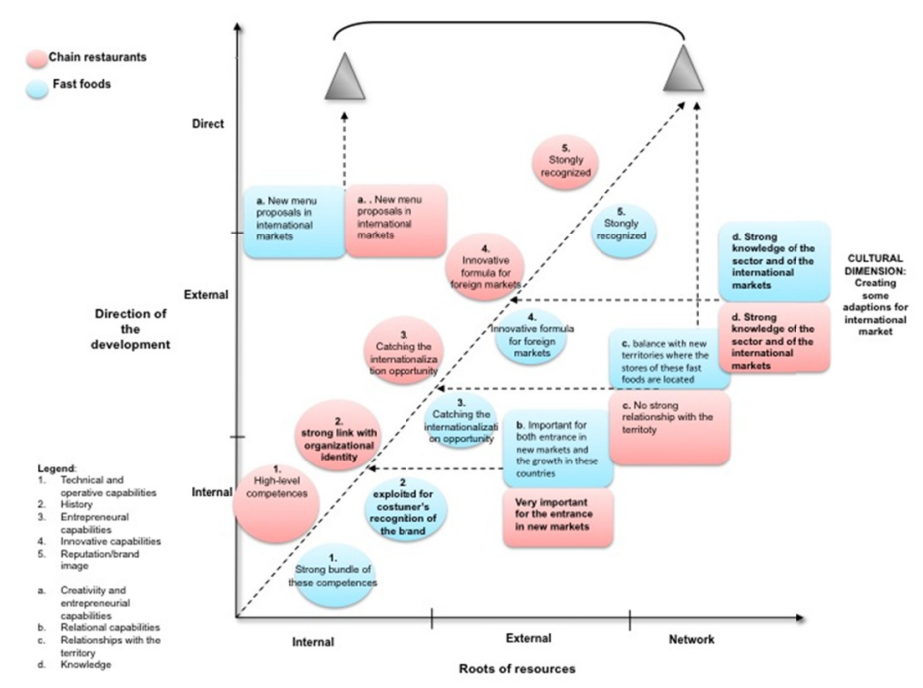

Figure 4. Chain restaurants and fast foods: main sources of the internationalization process

Source: Our Elaboration.

\section{Conclusions}

The focus of this paper on the sources of internationalization rather than on the process has led to the search of the mix of capabilities that can originate as well as sustain the internationalization process.

This is the reason why the research moved its first steps in the theoretical roots of internationalization, identifying the main referring models that explain the source of this process.

This kind of approach represented an attempt to favour advances in theory on internationalization, supported by an empirical analysis. Indeed, as all theoretical models, conceptualizations hardly describe the real word. From here, after the analysis of the main models, this research proposed the International resource-based model (Della Corte, 2014) as it decomposes the internationalization process, capturing the main sources that create and support the internationalization strategy.

In particular, this paper considered a precise angulation since the focus of analysis is on both relational and identity-making capabilities. These latters are analyzed in the light of empirical observations.

As the results demonstrate, both relational and identity-making capabilities are fundamental in the internationalization process. Relations, indeed, can generate market knowledge, experiential knowledge, cultural knowledge and entrepreneurial knowledge with reference to the international markets. Hence, it is very important that firms that internationalize own this kind of capabilities. The proposed analysis demonstrates that fast foods, chain restaurants and single location full-service restaurants possess relational capabilities but only fast foods and chain restaurants exploit them in order to internationalize.

On the other side, the identity-making capabilities are necessary for the entrance as well as the growth and the stability in international markets. Paradoxically, single location full-service restaurants that have a high degree of identity-making capabilities do not internationalize; identity-making capabilities of fast foods and chain restaurants try to act on the identity elements (i.e., history, brand) that can generate trust in the consumer. What also happens during internationalization is the loss of identity, in terms of linkages with the territory of origin. The local identity is found when chain restaurants adopt the local concept for the preparation of dishes or for the internal setting of the stores. In this case the brand of these restaurants fully express the belonging to the territory of origin. In other cases, as in the fast food cluster, the commercial proposals of these restaurants encounter the cultural dimension of the foreign markets in terms of tastes and preferences. Hence, for some firms the choice of internationalization can signify the loss of original identity.

Therefore, US fast foods have a higher degree of internationalization (Moonkyu \& Ulgado, 1997; Walker \& Etzel, 1973), as they "reflect worldwide acceptance of American cultural values" (Qui, 2014, p. 102) compared with chain restaurants, whose degree of internationalization is low. These are the so-called "restaurants in which customers order and pay at a counter" and their profitability mostly depends on "efficient operations and effective marketing" (Statistica, 2015). The analysis showed that also the cultural dimension plays a key role in 
the internationalization process. Indeed in the light of this element, both fast foods and restaurant chains revisit their offer in the international context, adapting to the new customer's needs and tastes.

The case of single location full-service restaurants is different as, in this industry, internationalization is "non-existent".

These results are also useful in the light of managerial implications. This research suggests, indeed, a greater attention on the identity-making capabilities that constitute the distinctive endowment of the firms.

From this point of view, it would be extremely interesting to extend the research to non-US restaurant firms, even if the comparison with Europe would require considering each single country. Europe, in fact, shows a variety of configurations and culinary cultures that are so different that they cannot be considered on the whole. A very interesting country, for this sector, is Italy because of the international fame of the made in Italy cuisine. An there are very interesting cases of medium enterprises that have become international in their governance structure (with the entrance in the equity of a foreign fund) and that are carrying out an Internationalization strategy that, however, is strongly based on their Neapolitan identity, both in the used products and in the country of origin of cooks and pizza cooks (rigorously Neapolitan), as well as of the waiters. These aspects, however, will be object of further study in a very interesting and challenging research.

\section{References}

Aaboen, L., Dubois, A., \& Lind, F. (2012). Capturing processes in longitudinal multiple case studies. Industrial Marketing Management, 41(2), 235-246.

Aarikka-Aarikka-Stenroos, L., Sandberg, B., \& Lehtimäki, T. (2014). Networks for the commercialization of innovations: A review of how divergent network actors contribute. Industrial Marketing Management, 43(3), 365-381. http://dx.doi.org/10.1016/j.indmarman.2012.01.009

Abecassis-Moedas, C., Ben Mahmoud-Jouini, S., Dell'Era, C., Manceau, D., \& Verganti, R. (2012). Key Resources and Internationalization Modes of Creative Knowledge - Intensive Business Services: The Case of Design Consultancies. Creativity and Innovation Management, 21(3), 315-331. http://dx.doi.org/10.1111/j.1467-8691.2012.00646.x

Aharoni, Y. (1966). The foreign investment decision process. The International Executive, 8(4), 13-14.

Andersen, O. (1993). On the internationalization process of firms: A critical analysis. Journal of International Business Studies, 24(2), 1-26.

Anwar, S. T. (2015). Super-Connectors: A New Model of Internationalization from the MENA Region. Thunderbird International Business Review, 57(2), 163-180.

Appelbaum, A. (2014). War and McPeace. Russia's ban on Western imports exposes the myth that global trade could end global conflict.

Augier, M., \& Teece, D. J. (2007). Dynamic capabilities and multinational enterprise: Penrosean insights and $\begin{array}{llll}\text { omissions. } & \text { Management } & \text { International }\end{array}$ http://dx.doi.org/10.1007/s11575-007-0010-8

Autio, E., George, G., \& Alexy, O. (2011). International entrepreneurship and capability development - qualitative evidence and future research directions. Entrepreneurship Theory and Practice, 35(1), 11-37. http://dx.doi.org/10.1111/j.1540-6520.2010.00421.x

Barney, J. (1991). Firm resources and sustained competitive advantage. Journal of management, 17(1), 99-120.

Barrows, C. W., \& Powers, T. F. (2009). Introduction to the hospitality industry (p. 514). New York, NY: John Wiley \& Sons.

Brunninge, O., Nordqvist, M., \& Wiklund, J. (2007). Corporate governance and strategic change in SMEs: The effects of ownership, board structure and top management teams. Small Business Economics, 29(3), 295-308. http://dx.doi.org/10.1007/s11187-006-9021-2

Calof, J. L., \& Beamish, P. W. (1995). Adapting to foreign markets: Explaining internationalization. International Business Review, 4(2), 115-131. http://dx.doi.org/10.1016/0969-5931(95)00001-G

Cassiman, B., \& Golovko, E. (2011). Innovation and internationalization through exports. Journal of International Business Studies, 42(1), 56-75.

Cavusgil, S. T. (1980). On the internationalization process of firms. European Research, 8(6), 273-281.

Chen, H. L. (2011). Does board independence influence the top management team? Evidence from strategic 
decisions toward internationalization. Corporate Governance: An International Review, 19(4), 334-350. http://dx.doi.org/10.1111/j.1467-8683.2011.00850.x

Contractor, F. J. (2007). Is international business good for companies? The evolutionary or multi-stage theory of internationalization vs. the transaction cost perspective. Management International Review, 47(3), 453-475.

Covin, J., Miller, D. (2014). International entrepreneurial orientation: Conceptual considerations, research themes, mesaurement issues, and future research directions. Entrepreneurship Theory and Practice, 38(1), $11-44$.

Cyert, R. M., \& March, J. G. (1963). A behavioral theory of the firm. Englewood Cliffs, NJ.

Darkow, I. L., Weidmann, M., \& Lorentz, H. (2015). Adaptation of foreign logistics service providers' resources and capabilities to a new institutional environment. Journal of Supply Chain Management, 51(1), 27-51. http://dx.doi.org/10.1111/jscm.12068

Della Corte, V. (2009). Imprese e sistemi turistici: il management. Egea.

Della Corte, V. (2013). Imprese e sistemi turistici: il management. II Edizione. Egea.

Della Corte, V. (2014). Towards a New Model of SMEs' Internationalization. In Strategic Management in Small and Medium Enterprises: Theory and Practice, Kiril Todorov, David Smallbone, IGI-Global.

Devece, C. A., Palacios-Marques, D., \& Fernandez, R. (2011). Entrepreneurship research in service industries: A literature classification and trend analysis. International Entrepreneurship and Management Journal, 7(4), 479-493. http://dx.doi.org/10.1007/s11365-011-0205-0

Dickson, P. (2015). The adoption of customer service improvement practices. Marketing Letters, 26(1), 1-15. http://dx.doi.org/10.1007/s11002-013-9263-0

Dyer, J. H., \& Singh, H. (1998). The relational view: Cooperative strategy and sources of interorganizational competitive advantage. Academy of Management Review, 23(4), 660-679. http://dx.doi.org/10.5465/AMR.1998.1255

Eisenhardt, K. M. (1989). Building theories from case study research. Academy of Management Review, 14(4), 532-550. http://dx.doi.org/10.5465/AMR.1989.4308

Eisenhardt, K. M., \& Graebner, M. E. (2007). Theory building from cases: Opportunities and challenges. Academy of Management Journal, 50(1), 25-32. http://dx.doi.org/10.5465/AMJ.2007.24160888

Eisenhardt, K. M., \& Martin, J. A. (2000). Dynamic capabilities: What are they? Strategic Management Journal, 21(10-11), http://dx.doi.org/10.1002/1097-0266(200010/11)21:10/11<1105::AID-SMJ133>3.0.CO;2-E

1105-1121.

Erramilli, K. M. (1990). Entry mode choice in service industries. International Marketing Review, 7(5). http://dx.doi.org/10.1108/EUM0000000001535

Eves, A., \& Dervisi, P. (2005). Experiences of the implementation and operation of hazard analysis critical control points in the food service sector. International Journal of Hospitality Management, 24(1), 3-19. http://dx.doi.org/10.1016/j.ijhm.2004.04.005

Gankema. H. G., Snuif, H. R., \& Zwart, P. S. (2000). The internationalization process of small and medium-sized enterprises: An evaluation of stage theory. Journal of Small Business Management, 38(4), 15-27.

Gimeno, J., Folta, T., Cooper, A., \& Woo, C. (1997). Survival of the fittest? Entrepreneurial human capital and the persistence of underperforming firms. Administrative Science Quarterly, 42, 750-783. http://dx.doi.org/10.2307/2393656

Helfat, C. E., \& Lieberman, M. B. (2002). The birth of capabilities: Market entry and the importance of pre-history. Industrial and Corporate Change, 11(4), 725-760. http://dx.doi.org/10.1093/icc/11.4.725

Hennart, J. F. (2007). The theoretical rationale for a multinationality-performance relationship. Management International Review, 47(3), 423-452. http://dx.doi.org/10.1007/s11575-007-0023-3

IBISWorld. (2015a). Well done: Restaurants conform to new trends to survive in a competitive market. IBISWorld Industry Report.

IBISWorld (2015b). Fine dining: Restaurants will rebound as consumer spending on dining out increase. IBISWorld Industry Report.

IBISWorld. (2015c). No so fast: Restaurants will expand their menus to retain customers in light of health 
concerns. IBIS World Industry Report.

IBISWorld. (2015d). Global Fast Food Restaurants. IBIS World Industry Report.

James, A. (2002). Global or local identities in contemporary British food cultures? Cross-cultural consumption: Global markets, local realities, 77 .

Jansson, H., \& Sandberg, S. (2008). Internationalization of small and medium sized enterprises in the Baltic Sea $\begin{array}{lllll}\text { Region. Journal of International } & \text { Management, } & \text { 14(1), } & \text { 65-77. }\end{array}$ Ehttp://dx.doi.org/10.1016/j.intman.2007.02.005

Johanson, J., \& Vahlne, J. E. (1977). The internationalization process of the firm-a model of knowledge development and increasing foreign market commitments. Journal of International Business Studies, 23-32.

Kalinic, I., \& Forza, C. (2012). Rapid internationalization of traditional SMEs: Between gradualist models and $\begin{array}{lllll}\text { born } & \text { globals. International } & \text { Business }\end{array}$ http://dx.doi.org/10.1016/j.ibusrev.2011.08.002

Kamakura, W. A., Ramón-Jerónimo, M. A., \& Gravel, J. D. V. (2012). A dynamic perspective to the internationalization of small-medium enterprises. Journal of the Academy of Marketing Science, 40(2), 236-251. http://dx.doi.org/10.1007/s11747-011-0267-0

Keen, C., \& Wu, Y. (2011). An ambidextrous learning model for the internationalization of firms from emerging economies. Journal of International Entrepreneurship, 9(4), 316-339.

Khalid, A. P. S., \& Larimo, J. (2012). Firm specific advantage in developed markets dynamic capability $\begin{array}{llll}\text { perspective. } & \text { Management }\end{array}$ http://dx.doi.org/10.1007/s11575-012-0137-0

Kiss, A. N., \& Danis, W. M. (2010). Social networks and speed of new venture internationalization during institutional transition: A conceptual model. Journal of International Entrepreneurship, 8(3), 273-287.

Klingebiel, R. (2012). Options in the implementation plan of entrepreneurial initiatives: Examining firms' attainment of flexibility benefit. Strategic Entrepreneurship Journal, 6(4), 307-334. http://dx.doi.org/10.1002/sej.1142

Kogut, B. (1985). Designing global strategies: Comparative and competitive value added chains. Sloan management review, 26(4).

Kogut, B., \& Zander, U. (1993). Knowledge of the firm and the evolutionary theory of the multinational corporation. Journal of International Business Studies, 625-645.

Lavie, D. (2006). The competitive advantage of interconnected firms: An extension of the resource-based view. Academy of Management Review, 31(3), 638-658. http://dx.doi.org/10.5465/AMR.2006.21318922

Li, L., Qian, G., \& Qian, Z. (2015). Speed of Internationalization: Mutual Effects of Individual-and Company-Level Antecedents. Global Strategy Journal, 5(4), 303-320. http://dx.doi.org/10.1002/gsj.1103

Lindstrand, A., Melén, S., \& Nordman, E. R. (2011). Turning social capital into business: A study of the internationalization of biotech SMEs. International Business Review, 20(2), 194-212. http://dx.doi.org/10.1016/j.ibusrev.2011.01.002

López-Duarte, C., Vidal-Suárez, M. M., \& González-Díaz, B. (2015). International Business and National Culture: A Literature Review and Research Agenda. International Journal of Management Reviews, 1-20. http://dx.doi.org/10.1111/ijmr.12070

McDonald's (2009). Proxy Statement Pursuant to Section 14(a) of the Securities Exchange Act of 1934. McDonald's.

Mejri, K., \& Umemoto, K. (2010). Small-and medium-sized enterprise internationalization: Towards the knowledge-based model. Journal of International Entrepreneurship, 8(2), 156-167. http://dx.doi.org/10.1007/s10843-010-0058-6

Melin, L. (1992). Internationalization as a strategy process. Strategic Management Journal, 13(S2), 99-118. http://dx.doi.org/10.1002/smj.4250130908

Miles, I. (2005). Innovation in services. In J. Fagerberg, D. C. Mowery, \& R. R. Nelson (Eds.), The Oxford Handbook of Innovation (pp. 433-458). Oxford: Oxford University Press.

Moonkyu, L. F., \& Ulgado F. M. (1997). Consumer evaluations of fast-food services: A cross-national 
comparison. Journal of Services Marketing, 11(1), 39-52. http://dx.doi.org/10.1108/08876049710158358

Musteen, M., Datta, D. K., \& Francis, J. (2014). Early internationalization by firms in transition economies into developed markets: The role of international networks. Global Strategy Journal, 4(3), 221-237. http://dx.doi.org/10.1002/gsj.1077

Nahapiet, J., \& Ghoshal, S. (1998). Social capital, intellectual capital, and the organizational advantage. Academy of Management Review, 23(2), 242-266. http://dx.doi.org/10.5465/AMR.1998.533225

Naldi, L., Achtenhagen, L., \& Davidsson, P. (2015). International corporate entrepreneurship among SMEs: A test of Stevenson's notion of entrepreneurial management. Journal of Small Business Management, 53(3), 780-800. http://dx.doi.org/10.1111/jsbm.12087

Nelson, R. R., \& Sidney, G. (2005). An evolutionary theory of economic change. Cambridge: Belknap.

Osarenkhoe, A. (2009). An integrated framework for understanding the driving forces behind non-sequential process of internationalisation among firms. Business Process Management Journal, 15(2), 286-316. http://dx.doi.org/10.1108/14637150910949498

Oviatt, B. M., \& McDougall, P. P. (2005). Defining international entrepreneurship and modeling the speed of internationalization. Entrepreneurship Theory and Practice, 29(5), 537-554. http://dx.doi.org/10.1111/j.1540-6520.2005.00097.x

Pagano, A. (2009). The role of relational capabilities in the organization of international sourcing activities: A literature review. Industrial Marketing Management, 38(8), 903-913. http://dx.doi.org/10.1016/j.indmarman.2009.02.007

Peng, M. W., Wang, D. Y., \& Jiang, Y. (2008). An institution-based view of international business strategy: A focus on emerging economies. Journal of International Business Studies, 39(5), 920-936. http://dx.doi.org/10.1057/palgrave.jibs. 8400377

Penrose, E. (1959). Theory of the Growth of the Firm. New York: John Wiley \& Sons.

Powers, T., \& Barrows, C. W. (1999). Introduction to the hospitality industry. John Wiley and Sons.

Quelch, J. A., \& Jocz, K. E. (2012). All business is local: Why place matters more than ever in a global, virtual world. Penguin.

Rao, T. R., \& Naidu, G. M. (1992). Are the stages of internationalisationempiricallysupportable? Journal of Global Marketing, 6(1-2), 147-170. http://dx.doi.org/10.1300/J042v06n01_08

Rathmell, J. M. (1974). Marketing in the service sector. Cambridge, MA: Winthrop.

Rediker, K. J., \& Seth, A. (1995). Board of directors and substitution effects of alternative governance mechanisms. Strategic Management Journal, 16(2), 85-99. http://dx.doi.org/10.1002/smj.4250160202

Rialp, A., Rialp, J., \& Knight, G. A. (2005). The phenomenon of early internationalizing firms: What do we know after a decade (1993-2003) of scientific inquiry? International Business Review, 14(2), 147-166. http://dx.doi.org/10.1016/j.ibusrev.2004.04.006

Robert, J. S. (2014). The McDonald's theory of international relations. Charleston Daily Mail.

Rodgers, S. (2007). Innovation in food service technology and its strategic role. International Journal of Hospitality Management, 26(4), 899-912. http://dx.doi.org/10.1016/j.ijhm.2006.10.001

Rodgers, S. (2008). Technological innovation supporting different food production philosophies in the food service sectors. International Journal of Contemporary Hospitality Management, 20(1), 19-34. http://dx.doi.org/10.1108/09596110810848541

Rogers, E. M. (1962). Diffusioni of innlovationis. New York: The Free Press.

Ruzzier, M., Hisrich, R. D., \& Antoncic, B. (2006). SME internationalization research: Past, present, and future. Journal of small business and enterprise development, 13(4), 476-497. http://dx.doi.org/10.1108/14626000610705705

Samiee, S. (1999). The internationalization of services: trends, obstacles and issues. Journal of Services Marketing, 13(4/5), 319-336. http://dx.doi.org/10.1108/08876049910282574

Schumpeter, J. A. (1934). The theory of economicdevelopment. Cambridge, Mass.: Harvard.

Scott, P., Gibbons, P., \& Coughlan, J. (2010). Developing subsidiary contribution to the MNC-Subsidiary entrepreneurship and strategy creativity. Journal of International Management, 16(4), 328-339. 
http://dx.doi.org/10.1016/j.intman.2010.09.004

Seaman, P., \& Eves, A. (2006). The management of food safety-The role of food hygiene training in the UK service sector. International Journal of Hospitality Management, 25(2), 278-296. http://dx.doi.org/10.1016/j.ijhm.2005.04.004

Statistica. (2015). Most valuable fast food brands worldwide in 2015. Statistica.

Todd, P. R., \& Javalgi, R. R. G. (2007). Internationalization of SMEs in India: Fosteringentrepreneurship by leveraging information technology. International Journal of Emerging Markets, 2(2), 166-180. http://dx.doi.org/10.1108/17468800710739234

Tuppura, A., Saarenketo, S., Puumalainen, K., Jantunen, A., \& Kyläheiko, K. (2008). Linking knowledge, entry timing and internationalization strategy. International Business Review, 17(4), 473-487. http://dx.doi.org/10.1016/j.ibusrev.2008.02.003

Vernon, R. (1971). Sovereignty at Bay: the multinational spread of Us enterprises. The International Executive, 13(4), 1-3. http://dx.doi.org/10.1002/tie.5060130401

Walker, B. J., \& Etzel, M. J. (1973). The internationalization of US franchise systems: Progress and procedures. The Journal of Marketing, 38-46. http://dx.doi.org/10.2307/1250050

Welch, L. S., \& Luostarinen, R. (1988). Internationalization: Evolution of a concept. Graduate School of Management, Monash University.

Wrigley, N. (2000). Strategic market behaviour in the internationalization of food retailing-Interpreting the third wave of Sainsbury's US diversification. European Journal of Marketing, 34(8), 891-919. http://dx.doi.org/10.1108/03090560010331388

Yin, R. K. (2003). Case study research: Design and methods. Thousand Oaks, CA: Sage Publications.

Zahra, S. A., Neubaum, D. O., \& Naldi, L. (2007). The effects of ownership and governance on SMEs' international knowledge-based resources. Small Business Economics, 9, 309-327. http://dx.doi.org/10.1007/s11187-006-9025-y

Zahra, S. A., Sapienza, H. J., \& Davidsson, P. (2006). Entrepreneurship and dynamic capabilities: A review, model and research agenda. Journal of Management studies, 43(4), 917-955. http://dx.doi.org/10.1111/j.1467-6486.2006.00616.x

Zain, M., \& Ng, S. I. (2006). The impacts of network relationships on SMEs' internationalization process. Thunderbird International Business Review, 48(2), 183-205. http://dx.doi.org/10.1002/tie.20092

Zhang, Z., Zhang, Z., \& Law, R. (2013). Regional effects on customer satisfaction with restaurants. International $\begin{array}{llll}\text { Journal of Contemporary Hospitality } & \text { Management, 25(5), }\end{array}$ http://dx.doi.org/10.1108/IJCHM-Aug-2012-0148

Zollo, M., \& Winter, S. G. (2002). Deliberate learning and the evolution of dynamic capabilities. Organization Science, 13(3), 339-351. http://dx.doi.org/10.1287/orsc.13.3.339.2780

\section{Note}

Note 1. Another model is the integrated framework of the enablers of a non-sequential internationalization that considers the incremental decisions as the output for the internationalization. While in other models, as for example the U-model, "the outcome of one decision - or more generally one cycle of events - constitutes the input of the next" (Osarenkhoe, 2008, p. 2), this model supposes that, during the internationalization process, firms can also skip certain stage, expected in the other models.

\section{Copyrights}

Copyright for this article is retained by the author(s), with first publication rights granted to the journal.

This is an open-access article distributed under the terms and conditions of the Creative Commons Attribution license (http://creativecommons.org/licenses/by/3.0/). 